\title{
University as an Environment for Shaping Key Teachers' Competence for Knowledge Society
}

\author{
Barbara Kedzierska \\ European Centre for Lifelong Learning and Multimedia Education, \\ Pedagogical University of Krakow, Podchorazych 2, \\ 30-084 Krakow, Poland \\ kedzierska@inf.up.krakow.pl
}

\begin{abstract}
Dynamic development of information \& communication technologies determines the changes, which more and more often are taking place in all spheres of life of a contemporary human being, forcing him to lifelong learning process, which will allow him to acquire and develop social and professional competence, but first and foremost the most important ones - key competence. Synchronous and asynchronous tools of digital communication stimulate the globalization of processes and services, making people independent from time and place and Internet sources of dispersed and diversified in form information force into responsible autonomy. The following text tries to answer the questions: Does contemporary education take into consideration these determinants and needs of contemporary society? How should a didactic process look like so that university graduates can be prepared to responsible and creative social and professional activity?
\end{abstract}

Keywords: university in lifelong learning process, key competence in university education, key competence of teachers, changes in contemporary education.

\section{Introduction}

Technological standards, which are the consequence of a dynamic (in a continuous way) development of information \& communication technologies and multiplying processes of globalization (economy, labour market, services, culture) are perceived nowadays as main factors of the changes taking place in all the areas in which societies function [1] . Constant development of particular scientific disciplines and wider and wider range of possibilities of modern ICT tools decide about the increasing pace of changes of our everyday life determinants, both in professional and social aspect. The only way to maintain professional activity on constantly changing labour market is becoming the competence, which strictly correspond with employers' expectations "here and now" [3], which means that acquiring, completing and improving competence (professional and social) has to last lifelong in a continuous way - regardless of someone's profession and age. And this creates for educational system challenges, unknown in history. 


\section{Key Competence for Lifelong Learning}

Lifelong learning is becoming a key process for everyone in knowledge based society; it is becoming a strategy, which decides not only about the present, but above all about the future of particular individuals, societies and the world itself. The superior programme for cooperation in Europe is Lifelong Learning Programme, which aims at adjusting to the most important social needs formal education, which is and will stay priority for democracy.

The authorities of countries and continents, conscious of these determinants, define the assumptions of the concept of lifelong learning which, integrating formal, non formal and informal education into one homogenous system, forces the changes to ensure the effectiveness of shaping and developing competence; professional and social ones, but first of all key competence. The notion of key competence was defined in the Attachment to the Recommendation of European Parliament and the Council from 18. December 2006 - Key Competence in Lifelong Learning - European Reference Framework [6]. Shaping them has become one of the main aims of Operational Programme Human Capital for 2007-2013.

The competence was defined in the document as the combination of knowledge, skills and suitable in a given situation attitudes. However, key competences are the ones we all need (regardless of age and profession) to self-realization and personal development, to professional, social and civil activity. In the document 8 key competences were defined, which specify 8 priority areas of activity of contemporary man, however, depending on the context of discussed issues of modern system of education, within particular projects [9], programmes or institutions, various suggestions of key competences are formed [7].

Generalizing, one may assume that key competences concern:

- $\quad$ self-assessment, planning and effective realization of one's education,

- communication and cooperation in heterogeneous teams,

- peaceful and creative problem solving,

- effective operating (processing) of information,

- $\quad$ integration of information \& communication technologies in the realized tasks,

- $\quad$ practical dimension of knowledge.

The main aim of modern educational system is to create among children and young people a conscious need and ability of effective learning, perceived as the solely efficient way of flexible adjusting to changing professional and social determinants. An exceptional role to fulfill has nowadays university education, which as the last stage of formal education for the majority of young people, should on one hand - improve key competence on the level which ensures independent and responsible learning in the next part of life, and on the other hand - prepare to satisfying entrance and activity on labour market.

Modern ways of communicating and free access to unlimited sources of diversified in form information, change the way a man functions in all his areas. In particular, are seen the changes taking place in education - the transformation is now absolutely 
necessary, because the first time in history children become teachers for their parents. Students have access to almost the same sources of information and knowledge as their teachers and what is more important, they make use definitely more efficiently of technological tools of acquiring, processing and presenting information [2] . In such situation, instead of transmission of information or codified knowledge, a teacher should teach young people to operate the information effectively (acquire, process, present and effectively use) in the realization of assumed aims and tasks.

Teacher's role is changing [4] and dynamical determinants of globalizing labour market force employees to current development and acquisition of new competence, which will enable the professional stability and professional/geographical mobility. In this situation a modular system of education and training, correlated with European and National Qualifications Framework seems to be inevitable. It will be able to help every single individual on each stage of life to keep up with the transformations taking place in everyday reality.

Due to global process of changes implying irreversible social and economic consequences there exists the need for constructive discussion and cooperation between universities and scientific/research centers in the field of adjusting the process of education to the needs and determinants of contemporary society.

Globalization of almost all areas of human activity and the geographical/professional mobility constitute the basis for elaborating the European Qualifications Framework, which determine a new way of interpreting qualifications in the whole Europe, becoming a fundamental European point of reference for national systems of education and local qualifications frameworks. So that according to the European Qualifications Framework and European Concept of Lifelong Learning (LLL) education could nowadays meet global challenges, redefinition of the system of education seems to be crucial; it should be thought over and it should take into consideration social and technological determinants of contemporary society, involving all levels particularly university level.

\section{Challenges for University Education}

The basis for functioning in constantly changing labour market today is competence [5] - professional and also, and perhaps first of all - key competence, which determine not only professional but also social activity - regardless of age, profession or social environment. Therefore, key competence as a primary key for any activity of a man, should be shaped in a spirally increasing way from the first year of human's life in all forms of education: formal, informal and non formal [3]. University system of education has a particular role to fulfill in this respect, which - preparing directly to active entrance on labour market, should ensure a proper preparation to all its graduates.

Although key competence should be perceived as inalienable in every profession, in a particular way they determine the effectiveness of teachers' work, from whom for centuries and millennia, society has expected the preparation of young people to professional and social activity in a reality conditioned in a multicontext way. Such assumption imposes a very responsible task on universities educating teachers, the realization 
of which requires international cooperation ${ }^{1}$ of institutions and people engaged in defining, directing, realization, evaluation and financing of the process of education. Globalization is gathering more and more pace [1] and it also concerns education; and the cooperation, which bases on the mobility of learners, students and scientists will be more effective if national systems of education refer to common guidelines and paradigms.

Undoubtedly, one must rank the following among the most significant international points of reference for the systems of education and improvement:

1. European Concept of Lifelong Learning and

2. European Qualifications Framework.

These are the documents which complement each other - the first one pays attention to the need for perceiving lifelong education of a single person as one continuous process, which lasts from birth to death. However, the second one specifies common for European countries assumptions and guidelines concerning the structure of system and the competence shaped on particular stages of education ${ }^{2}$.

The dynamic development of information \& communication technologies - particularly the Internet - has revolutionized forms of communication, offers virtual reality full of illusions/appearances and a free access to almost unlimited resources of information is assumed to be episodic and hypertext [1]. Such determinants are changing radically not only the way contemporary man functions, but also his way of learning and thinking. The competence of effective processing and using information is nowadays becoming more important than the ability of gaining indispensable information. We can no longer shape knowledge on the basis of successively built linear structure, since the fragmentary transmission of information forces hypertext structure. It is becoming more and more obvious that in such revolutionarily new conditions, forms and methods that have been used for centuries cease to be effective and the basic assumptions of the system of education require revision and redefinition. What one should do, therefore? How to define the aims? Which forms and

\footnotetext{
${ }^{1}$ Within such cooperation, in Krakow in October 2009 international scientific conference took place: Changes in Contemporary Education; Digital Potential versus Cognitive Traps. Key Competences in the Knowledge Society for e-Inclusion, whose Final Document constitutes a specific voice in international discussion concerning the direction and range of indispensable nowadays changes, which determine adjusting education to social needs and economic/technological determinants. The majority of recommendations formulated by the participants finds their reference to the determinants of academic education not only in European countries, but also on other continents; so, in order to not "reinvent the wheel" but synergistically work out common direction and a range of activities for contemporary education, which will guarantee its effectiveness and sustainability, it is worth to take into consideration already elaborated conclusions.

${ }^{2}$ To aforementioned definitions and recommendations refers Final Document of Krakow Conference, which in the form of Memorandum and a set of Recommendations suggests activities, which aim at adjusting university education to economic/technological determinants of contemporary society. International debate was organized by European Centre for Lifelong Learning and Multimedia Education at Pedagogical University in cooperation with International Foundation for Information Processing (IFIP), that is why the postulates, in a particular way concern the process of education and training of teachers, whose competence have the influence on the preparation of next generations to satisfying life in constantly changing reality.
} 
methods of education to admit so that contemporary education will fulfill social expectations and respond to the changing economic/technological determinants?

The superior and timeless aim of education is to prepare children and youth to active, responsible and creative professional/social activity on next stages of life. Such a formulated aim makes forms and methods of education dependent on forms and methods of social/professional activity (the change of functioning in society should in an automatic way imply the change of way of educating and improving one's skills). Therefore, if contemporary forms and methods of social/professional activity differ so much from those from 20.-30. years ago, so - consistently, forms and methods which prepare to such activities should also be changed [2].

One of the most important consequences of information revolution has become the necessity for lifelong learning and improving one's skills; European Concept of Lifelong Learning perceives all the forms of education (formal, non formal, informal) as elements of one continuous lifelong process; thus, university education should be an integral - synchronized with the remaining ones, element of this process [8]. On one hand, it should take into consideration and acknowledge the competence of students acquired outside a university, and on the other, it should shape the competence helpful and indispensable in post-university activity. Ensuring the quality and effectiveness of university education requires that acknowledgement of beyond-university education and training is determined with a consistent certification of the institutions that participate in the process of lifelong learning.

It seems indispensable, therefore, to work out the procedures of recognition of qualifications acquired beyond the system of formal education (in the assessment of student's achievements effects of non formal and informal education should be taken into account). One should also sanction the recognition of foreign and national studies, accepting the alternation of the pace of studying at the same time.

Priority, it becomes modular educational offer [2], which replaced the rigid structure of the curriculum will allow for flexible and dynamic adjustment of graduate education to changing labor market conditions [5]. Shorts form of education, which base on modules, enable dynamic completion and development of competence, which employers look for "here and now". Educational offer should take into consideration applicational dimension, complexity of knowledge and the preparation of graduates to active entrance on labour market requires effective cooperation of universities with employees. The examples of good practices are: commonly defined curricula, classes at university conducted by the management of enterprises or student's practice integrated with the activity of companies. In order to ensure the effectiveness and quality of academic didactic process, inner - university systems of ensuring the quality of education are becoming indispensable, among others through current monitoring and evaluation. Single examples show that history of professional carriers of graduates constitutes an important element of the system of evaluation of the quality of university education.

A matter of priority importance for social/professional activity in knowledgebased society is key competence; although they should be shaped in a spiral way on all stages of education, university education constitutes for the majority of young people the last stage of preparation to independent and responsible life in globalizing society determined technologically so strongly [3]. Taking into consideration the fact that more important than informational \& communication tools themselves are today 
the consequences of their presence in our life deciding about completely new standards of both social and professional functioning, universities have a very responsible task to fulfill. These are universities that should create the following abilities of:

$>$ flexible adjusting to changing determinants of labour market,

$>$ critical and creative thinking,

$>$ analytical problem solving,

$>$ both individual and team work,

$>$ responsible conducting one's professional carrier,

$>$ independent learning and effective use of wisely selected and effectively processed information.

Episodic and hypertext transmission of information no longer allows in the process of shaping knowledge to base on linear structures. Therefore, if technological determinants modify the cognitive process of a human, the revision and redefinition of basic assumptions of didactic process - also academic one is becoming a necessity[2].

According to cognitivistic paradigm, activating methods are becoming a basic form of didactic activities, what means that different forms of transmission of information/knowledge (lectures/classes) should be replaced by the activities which force independent work within interdisciplinary projects realized in small groups during practical or conversation classes, seminars or workshops. And the traditional methods of theoretical control of knowledge or competence of a student should be replaced with the process of systematic evaluation of assumed effects of education and competence of a student, who participates in the realization of group projects which are based on a synergic cooperation.

As comparative analysis of university education in different countries all over the world shows, adjusting academic didactic process to the needs and challenges of creating knowledge-based society, is determined with suitable priorities of a university, among which the preparation and the competence of university teachers are of significant importance. The role of a moderator or tutor, which university teacher should nowadays fulfill, requires the authority, which depends in a direct way from their pedagogical/discipline competence, updated in a continuous way in the process of lifelong learning. University teachers should be obliged to constant (cyclical) completing and broadening their knowledge and skills in a discipline, pedagogical and didactic field; lifelong development of university teachers (LLL) should take place in a planned way (coordinated by academic centres of lifelong learning).

Clear need for defining a set of key pedagogical competence for university teachers is visible. Among them what seems inalienable is full, effective and transparent integration of the potential of information \& communication technologies in a didactic process [2]. It does not refer to compulsory use of multimedia during classes and basing exclusively on Internet sources of information; what is more important is the choice of proper forms and methods of education having applicational dimension, preparing students to responsible independence in the future job they are preparing themselves for. Activating methods in a university process of education should take into consideration technological determinants of everyday life, electronic forms of communication, episodic and hypertext transmission of information; they should shape the competence of flexible adjusting to the changing labour market and new forms of activity in globalizing society. 


\section{Conclusion}

Results of international comparative studies show that the process of adjusting academic education to technological determinants and social needs should take into consideration above all the following:

$>$ the reorganization of didactic process, which would force change of teaching into learning,

$>$ change of teacher's role from information and codified knowledge transmitter to a guide, supervisor and moderator; a teacher should become a lifelong learner,

$>$ the replacement of statistic forms of teaching with activating methods, which shape creativity, responsibility and responsible autonomit,

$>$ transparent integrating of the potential of modern media with all elements of a didactic process.

Efficiency of such changes depends, of course, on the activity and cooperation on international (European) and country level (proper documents and regulations); however a direct efficacy is determined with the conscience and competence of teachers, who by the synergistic cooperation with students and their parents are able in a possibly shortest period of time change educational practice on all levels of education.

\section{References}

1. Bron, A., Schemmann, M. (eds.): Knowledge Society, Information Societty and Adult Education. Trends, Issues, Challenges, Munster (2003)

2. Kedzierska, B.: The Role of Audiovisual Means in Lifelong Learning. In: Audiovisual Anthropology: Theory and Practice International Conference, Moscow, pp. 269-274 (2008)

3. Kedzierska, B.: Kompetencje informacyjne w kształceniu ustawicznym. IBE Warsaw (2007)

4. Kedzierska, B., Frankowicz, M.: New Information and Communication Technology and Changing Roles of Teachers. In: Information \& Communication Technology in Natural Science education - 2006 EU Sixth Framework Programme, International research Project “ARiSE” Siauliai, Lithuania, pp. 35-38 (2006)

5. Kedzierska, B.: Kompetencje informacyjne w kształceniu zawodowym. In: Kwiatkowski, S.M. (ed.) Przedsiębiorstwo w rozwoju zawodowym pracowników, pp. 131-139. IBE, Warszawa (2007)

6. E-learning in Europe, http://www.elearningeuropa.info

7. EURIDICE, http: / / www. euridice.org

8. Ministry of Education in Poland, http://www. menis.gov.pl

9. OECD, The Definition and Selection of Key Competencies. Executive Summary, DeSeCo (2003), http: / /www. oecd.org/edu/statistics/deseco 